\title{
Penyediaan Rumah Baca Masyarakat Sebagai Solusi Cerdas Mengawali Budaya Membaca
}

\author{
Muhammad Ridwan Basalamah', Mohammad Rizal ${ }^{2}$, Erfan Efendi ${ }^{3}$ \\ 1,2,3 Program Studi Manajemen, Fakultas Ekonomi dan Bisnis, Universitas Islam Malang \\ *e-mail: Ridwanbasalamah@unisma.ac.id
}

\begin{abstract}
Public of Argoyuwono Village who are not well educated and have insufficient levels of economic capacity to send their children to higher levels of education, therefore, need the help of housing providers, to obtain information and assistance, this can lead to things that can be done to improve their standard of living. The method of this program is the provision of a reading house to give a new nuance and further and quality knowledge travel through books. The result of this program is that the people of Arguyuwono village are very happy with the existence of a reading house, because they believe that providing a reading house will be able to be a conducive place to build smart and superior generation in the village and this program is getting help from other parties, both from the village apparatus, Community leaders, teachers and also the general public.
\end{abstract}

Keywords: Public Reading House, Interest in Reading, Villagers, Reading Culture

\begin{abstract}
Abstrak
Masyarakat Desa Argoyuwono mayoritas belum berpendidikan tinggi dan tingkat kemampuan ekonomi yang belum cukup untuk menyekolahkan putra-putrinya sampai ke jenjang lebih tinggi, oleh karena itu, perlu suatu inovasi penyediaan rumah baca, untuk mendapatkan banyak informasi dan wawasan serta pengetahuan, hal ini dikarenakan dengan pengetahuan setidaknya masyarakat akan mengerti dan memahami hal - hal yang selama ini mereka abaikan dan anggap tidak penting menjadi sesuatu yang bisa bermanfaat untuk memperbaiki taraf hidup mereka. Metode Program ini adalah penyediaan rumah baca untuk memberikan nuansa baru dan berwisata pengetahuan lebih jauh dan bermutu melalui buku. Hasil dari program ini bahwa masyarakat desa Arguyuwono sangat senang dengan adanya rumah baca, karena mereka yakin penyediaan rumah baca ini akan mampu menjadi tempat yang kondusif untuk membangun generasi cerdas dan unggul di desa tersebut dan proram ini mendapatkan dukungan dari berbagai pihak, baik dari aparatur desa, tokoh masyarakat, para guru dan juga masyarakat umum.
\end{abstract}

Kata kunci: Rumah baca masyarakat, Minat Baca, Masyarakat Desa, Budaya Membaca

\section{PENDAHULUAN}

Rendahnya budaya membaca pada masyarakat Indonesia, mengakibatkan kurang berkembangnya ilmu pengetahuan dan teknologi di Indonesia (Nurul,2017). Rahim, (2008) menyebutkan bahwa orang yang mempunyai minat baca yang kuat akan diwujudkannya dalam kesediaannya untuk mendapat bahan bacaan dan kemudian membacanya atas kesadarannya sendiri. bahwa minat baca merupakan hasrat yang kuat seseorang baik disadari ataupun tidak yang terpuaskan lewat perilaku membacanya, Hasanah, (2011). Pengembangan minat baca ditingkatkan secara berkesinambungan agar terbentuk masyarakat yang berbudaya membaca (Kartika, 2014). Budaya baca dapat terbentuk dari berbagai aspek. Seperti keinginan atau minat baca yang meningkat dan kemudahan dalam mengakses sumber bacaan. Sehingga budaya baca ini dapat terbentuk. Selain itu frekuensi dan jumlah bacaan yang dibaca juga dapat mempengaruhi terbentuknya budaya baca ini (Harsiati \& Priyatni, 2018).

Desa Argoyuwono merupakan salah satu desa yang terletak di Kecamatan Ampel Gading, Kabupaten Malang. Batas wilayah Desa Argoyuwono yaitu meliputi: Sebelah Utara: Hutan Semeru Sebelah Selatan: Desa Sidorenggo, Desa Tirtomoyo, Sebelah Barat: Desa Mulyoasri, Sebelah Timur: Desa Sidomulyo Kec. Pronojiwo, Lumajang. Kenyataan desa Arguyuwono bahwa sebagian besar orang tua mereka berprofesi sebaga petani dan peternak yang asing dengan dunia pendidikan dengan berpenghasilan di bawah pendapatan rata-rata nasional. Mengacu pada keadaan sosial masyarakat desa Arguyuwono yang mayoritas belum berpendidikan tinggi dan tingkat kemampuan ekonomi yang belum cukup untuk menyekolahkan putra-putrinya sampai ke jenjang lebih tinggi. Menurut Bano, Jabeen, \& Qutoshi (2018) salah satu strategi efektif dalam 
mendorong minat anak-anak terhadap kegiatan membaca adalah dengan menyediakan bahan bacaan di lingkungan dirumah.

Melalui pembudayaan baca, masyarakat desa Arguyuwono akan meningkat pengetahuannya, meningkat tatanan ekonominya yang mana peningkatan tersebut akan mengurangi pengangguran dan kemiskinan. Dengan membaca pula seseorang akan terbentuk kepribadiannya menjadi lebih baik. Kepribadian adalah pola menyeluruh semua kemampuan, perbuatan serta kebiasaan seseorang, baik yang jasmani, mental, rohani, emosional maupun sosial. Pola ini terwujud dari tingkah laku dalam usahanya menjadi manusia sebagaimana dikehendakinya (Fifqi,2014).

Selanjutnya, Huriyah (2016) menyatakan bahwa perpustakaan keluarga bisa menjadi sarana yang paling tepat dalam penyediaan bahan bacaan, Selain itu, perpustakaan keluarga juga menjadi alternatif menghabiskan waktu. Dari pendapat inilah, Masyarakat desa Arguyuwono perlu diperhatikan dalam hal pengayaan ilmu pengetahuan karena dengan pengetahuan setidaknya masyarakat akan mengerti dan memahami hal - hal yang selama ini mereka abaikan dan anggap tidak penting menjadi sesuatu yang bisa bermanfaat untuk memperbaiki taraf hidup mereka. Dengan penyediaan rumah baca ini bisa memberi warna baru dan tambahan pengetahuan di lingkungan masyarakat desa yang masih banyak membutuhkan pembinaan disegala bidang, terutama pada anak - anak dan remaja yang lebih senang bermain handphone dari pada membaca, sehingga dengan keberadaan rumah baca ini bisa memberikan nuansa baru dan berwisata pengetahuan lebih jauh dan bermutu melalui buku. Seperti halnya taman baca masyarakat adalah tempat yang sengaja dibuat pemerintah, perorangan, atau swakelola dan swadaya masyarakat untuk menyediakan bahan bacaan dan menumbuhkan minat baca kepada masyarakat yang ada di sekitar taman baca masyarakat (Salvia,2014).

\section{METODE}

Metode yang digunakan dalam pengabdian ini adalah metode pembelajaran dan penyediaan rumah baca. Sasaran yang dipilih adalah masyarakat khususnya anak-anak di Desa Argoyuwono. Penetapan sasaran ini merupakan suatu upaya untuk meningkatkan kemauan atau keinginan membaca dan mempermudah mendapatkan buku referensi. Lebih jauh dari itu, harapannya bertujuan untuk membekali minat membaca pada masyarakat khususnya anak-anak di Desa Argoyuwono agar dapat menggunakan buku sebagai pedoman untuk masa depan. Adapun sistematika pelaksanaan pengabdian ini adalah sebagai berikut :

a. Sosialisasi pemahaman tentang Rumah Baca dan meningkatnya Minat Baca untuk masyarakat khususnya anak-anak di Desa Argoyuwono.

b. Pembangunan Rumah Baca dan Pengadaan Buku untuk masyarakat khususnya anak-anak di Desa Argoyuwono.

c. Pendampingan dan pengarahan tentang Rumah Baca dan pentingnya kesadaran akan budaya membaca.

d. Focus Group Discussion bersama stakeholder dan perwakilan masyarakat serta peresmian Rumah Baca.

e. Mengembangkan minat / budaya membaca serta melakukan pelatihan tentang manajemen kepustakaan tentang sistem literatur dan beberapa standar pelaksanaan rumah baca dan kesetaraan pemahaman akan manfaat Rumah Baca.

\section{HASIL DAN PEMBAHASAN}

\section{a. Sosialisasi Pemahaman Rumah Baca}

Program pengabdian masyarakat ini di awali dengan survey lokasi yang memungkinkan untuk dijadikan tempat perpustakaan yang dapat diakses dengan mudah oleh calon pembaca di desa Argoyuwono dalam hal ini diprioritaskan bagi anak-anak dan remaja yang membutuhkan berbagai macam sumber bacaan untuk memperkaya khasanah keilmuan mereka. Dalam melakukan sosialisai, tim pengabdi berkolaborasi dengan berbagai pihak. Pihak-pihak yang turut membantu sosialisasi ini yaitu dari pihak desa baik dari kepala desa sampai ke tingkat RT dan RW.

Peran pejabat desa memberikan peran yang sangat penting karena mereka sudah memiki kedekatan secara emosional serta memiliki power untuk membuat kebijakan. Selanjutnya adalah 
mahasiswa yang sedang KKN di desa tersebut. Selama KKN mereka juga turut serta mendukung mensosialiskan program ini. Mereka secara aktif mendorong siswa-siswa yang diajari untuk memiliki minat baca. Selain itu, mereka juga bekerja sama dengan para guru di desa tersebut di mana mereka juga mengabdi untuk mengajar. Berpikir stereotype dalam penanganan masalah siswa tentu masih belum maksimal hasilnya dalam membantu siswa untuk berkembang maksimal sesuai tingkat perkembangannya, karena bisa saja faktor penyebabnya berbeda, karena faktor pendorong sikap siswa bermasalah tersebut ada beberapa macam sumber pendorongannya baik orang, situasi dan kondisi lingkungan, tempat sebagai sumber akar masalah menyebabkan prestasi belajar rendah (Yuliansyah,2019).

Selain itu, hasil pengabdian ini sejalan dengan hasil pengabdian Warman, (2019) juga terjadi peningkatan motivasi dalam belajar dan kemampuan membaca dan berbicara mereka. Hal ini membuktikan bahwa program membaca memberikan dampak yang cukup baik. Selain itu, program ini juga memiliki dampak positif dari berbagai aspek antara lain aspek sosial, ekonomi dan pendidikan baik bagi anak-anak panti dan juga bagi sukarelawan yang terlibat. Berkat upaya yang maksimal serta kerja sama dari berbagai pihak, Hasil dari pengabdian ini mendapatkan tingkat kesuksesan sebesar $90 \%$ yang terlihat dari rampungnya penyediaan rumah baca dan pengadaan buku di perpustakaan tersebut. Selain itu, dalam proses tersebut juga diadakan FGD dan pendampingan terhadap berjalannya program tersebut. Dilihat dari jumlah antusiasme pengunjung juga sangat baik. Terbukti dari banyaknya pengunjung ke rumah baca semenjak tempat tersebut diresmikan.

\section{b. Penyediaan Rumah Baca Dan Pengadaan Buku}

Setelah melakukan survey lapangan, Pembangunan rumah baca ditempatkan di balai desa Argoyuwono dengan berbagai pertimbangan. Pertama, Balai desa merupakan fasilitas untuk masyarakat sehingga masyarakat tidak akan sungkan untuk berkunjung ke perpustakaan. Kedua, balai desa merupakan tempat aparatur desa melaksanakan tugas admisitratifnya. Dengan demikian, pegawai pemerintah desa juga akan ikut bertanggung jawab untuk menjaga mengawal dan mengembangkan perpustakaan yang telah diinisiasi oleh tim pengabdi. Hal ini diharapkan program perpustakaan akan terus berlanjut dan berkembang. Ketiga, adanya perpustakaan memberikan peluang lebih banyak bagi pegawai desa untuk berinteraksi dengan masyarakat yang mengantar anaknya atau ikut serta membaca di perpustakaan di Balai desa. Sehingga aspirasi dari rakyat akan lebih mudah untuk di dengar dan segera diaktualisasi.

Dalam rangka membuat rumah baca yang bagus, maka diperlukan sumber bacaan yang bagus dan variatif agar mampu memberikan banyak opsi bacaan bagi pengunjung dan bisa mengakomodasi kebutuhan dari pembaca yang berasal dari berbagai tingkat pendidikan dan usia. Untuk mewujudkan hal tersebut, maka dilakukan pengadaan buku diupayakan dengan beberapa cara, pertama, buku diadakan dengan dana dari tim pengabdian. Buku yang sudah disumbangkan berupa buku pelajaran, buku cerita, buku pertanian dan peternakan. Kedua, bantuan buku dari aparatur desa dan tokoh masyarakat sebagai bentuk kepedulian beliau terhadap kemajuan generasi muda dan masyarakat umum di desa tersebut. Ketiga, melalui charity dari mahasiswa dan masyarakat yang menyumbangkan buku. Dengan adanya program charity ini maka buku yang didapat juga semakin banyak dan variatif karena buku yang disumbangkan berasal dari berbagai kalangan dengan latar belakang keahlian yang berbeda-beda.

\section{c. Pendampingan Rumah Baca}

Demi menjaga kualitas penyelenggaraan dan sustainability dari perpustakaan yang sudah dibangun di desa Argoyuwono, maka diperlukan pendampingan yang efektif. Pendampingan yang dilakukan adalah dengan cara memberikan pelatihan tentang system pengelolahan perpustakaan yang efektif dan efisien. Adanya rumah baca yang baru tentu menjadi hak yang cukup asing bagi masyarakat setempat khususnya dalam cara pengelolaan dan peningkatannya. Oleh karena itu, perlu adanya pendampingan berupa pelatihan kepada petugas dan relawan yang akan menjadi pengelola rumah baca tersebut.

Disamping upaya pelatihan pengelolaan rumah baca, hal lain yang dilakukan adalah memberikan edukasi tentang strategi-stategi pengembangan sumber daya manusia melalui media 
membaca dan pendidikan. Tim pengabdi juga memberi arahan terkait program kerja yang bisa diterapkan di rumah baca tersebut seperti diskusi rutin, sharing session dengan relawan dari akademisi dan praktisi serta berbagai kegiatan lainnya yang mampu meningkatkan kualitas sumber daya manusia di desa Arguyuwono tersebut.

\section{d. FGD (Forum Grup Discussion)}

Dalam rangka memaksimalkan kinerja dari rumah baca yang sudah dibangun di desa Arguyuwono, maka kami adakan FGD dengan tema "Rumah Baca Masyarakat sebagai Solusi Cerdas untuk Mengawali Budaya Membaca" Kegiatan ini diikuti oleh aparatur desa dan masyarakat luas baik dari anak-anak, remaja maupun para orang tua. Jumlah peserta yang hadir di FGD ini 45 Orang. Kegiatan ini dilakukan pada tanggal 5 Desember 2019 Banyaknya partisipasi masyarakat yang ikut serta menghadiri agenda ini menunjukkan tingkat antusiasme masyarakat yang tinggi untuk ikut serta memajukan kegiatan ini. Dalam agenda ini dibahas tentang langkahlangkan konkrit untuk memaksimalkan rumah baca sebagai alat untuk mencerdaskan seluruh lapisan masyarakat di desa Argoyuwono.

Pemateri menitik beratkan pada beberapa aspek. Pertama, pemateri memberikan gambaran tentang dampak nyata dari peningkatan pengetahuan terhadap peningkatan kesejahteraan dan kemajuan sebuah masyarakat dengan memberikan contoh Negara-negara maju dengan tingkat minat baca tinggi dan tingkat kesejahteraan masyarakatnya seperti Finlandia, Kanada dan Selandia Baru. Dalam tahap ini, pemateri berupaya untuk meningkatkan awareness dan motivasi masyarakat untuk memiliki minat baca yang tinggi sebagai upaya untuk meningkatkan kualitas hidup masyarakat di desa itu.

Selanjutnya, pemateri juga memberikan langkah-langkah strategis untuk memastikan keberlangsungan rumah baca di desa tersebut. Pembahasan terkait dengan strategi untuk membuat masyarakat khususnya anak-anak dan remaja merasa tertarik untuk terus berkunjung ke perpustakaan, cara menginfentaris buku di rumah baca, perawatan buku dan bangunaan serta upaya-upaya lanjutan untuk meningkatkan jumalah buku agar bisa terus update dan mampu mengobati dahaga pengunjung terhadap informasi dan pengetahuan yang baru. Upaya ini dinilai sangat perlu karena rumah baca yang dibangun tentu tidak hanya sebagai upaya sementara namun agenda ini dimaksudkan agar bisa terus berkembang agar bisa menjadi sumber pengetahuan bagi masyarakat sekitar.

Hal lain yang juga disampaikan oleh pemateri adalah kisah sukses rumah baca yang sudah ada di Indonesia. Misalnya Rumah baca bintang yang menjadi pelopor literasi di desa terpencil yang berlokasi di Desa Sumberjosari, Kecamatan Karangrayung, Kabupaten Grobogan, Jawa Tengah. Rumah baca ini dimulai dengan kisah yang lebih susah dari rumah baca yang diadakan di desa Argoyuwono karena rumah baca Bintang dimulai dengan inisiatif perorangan sedangkan rumah baca di desa Argoyuwono merupakan upaya yang dilakukan secara sistematis dan didukung oleh berbagai pihak. Sehingga tentu saja rumah baca ini diharapkan bisa menjadi yang lebih baik dari rumah baca yang sudah ada di tempat lain.

Sesuai dengan garis besar pengabdian ini, maka dalam sesi ini diadakan diskusi antara pemateri, tim pengabdi, aparatur desa dan masyarakat. Semua dilakukan untuk memastikan upaya pembangunan rumah baca ini menjadi lentera terang bagi masyarakat yang memberikan hope bagi semua penggunanya tentang masyarakat yang lebih unggul, makmur dan sejahtera dengan lahirnya sunber daya manusia yang hebat. Dari diskusi tersebut didapatkan pula keputusan dari Kepala desa dan semua timnya yang sanggup berkomitmen untuk bersinergi dengan semua pihak terkait dalam rangka menjaga, mengaktifkan dan menambah jumlah koleksi buku untuk meningkatkan SDM di desa Arguyuwono tersebut. 


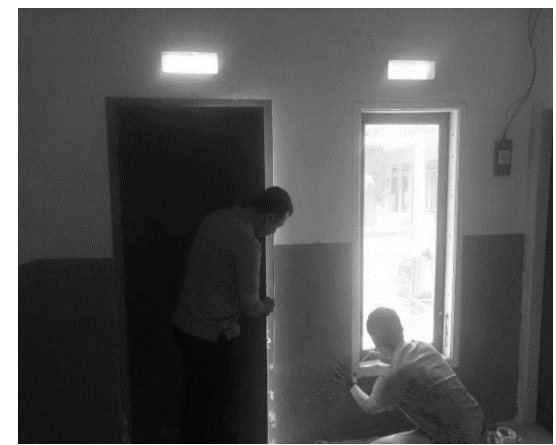

Gambar 1. Perbaikan rumah baca

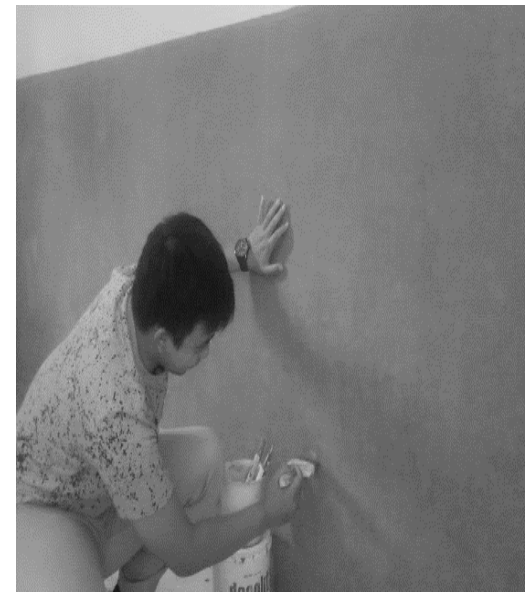

(a)

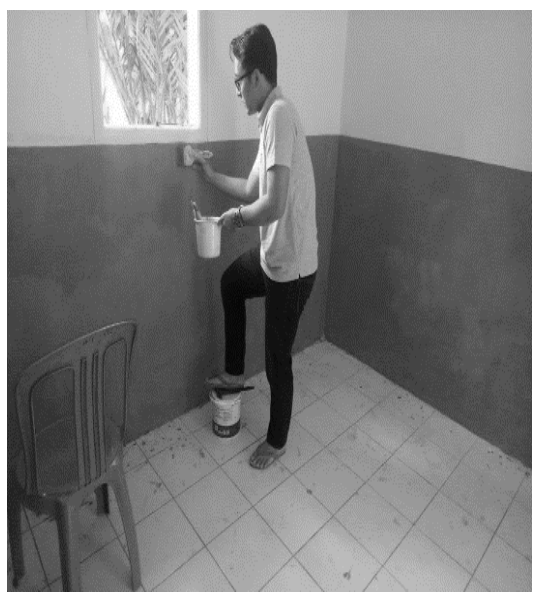

(b)

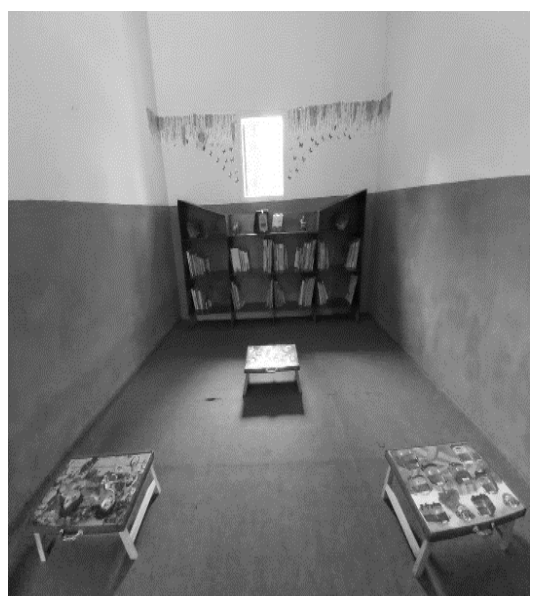

(c)

Gambar 2. Rumah baca (a) pengecetan bagian dalam (b) penyempurnaan (c) model rumah baca

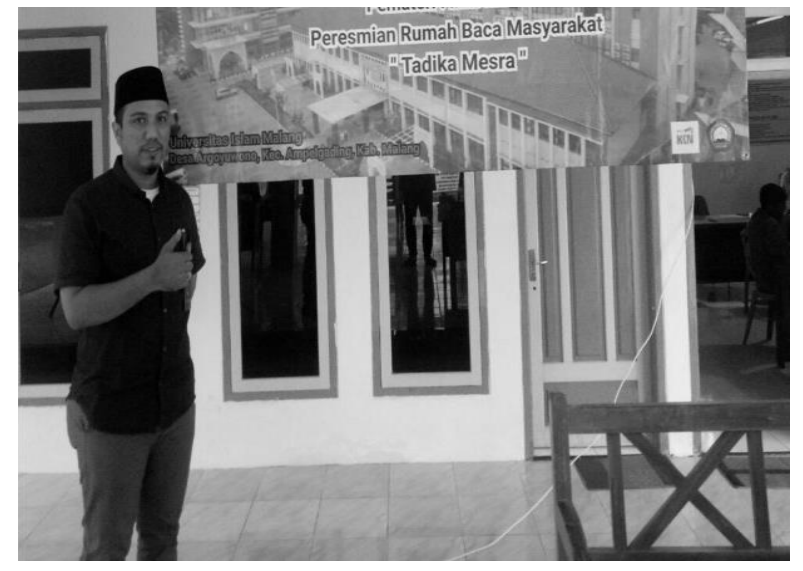

(d)

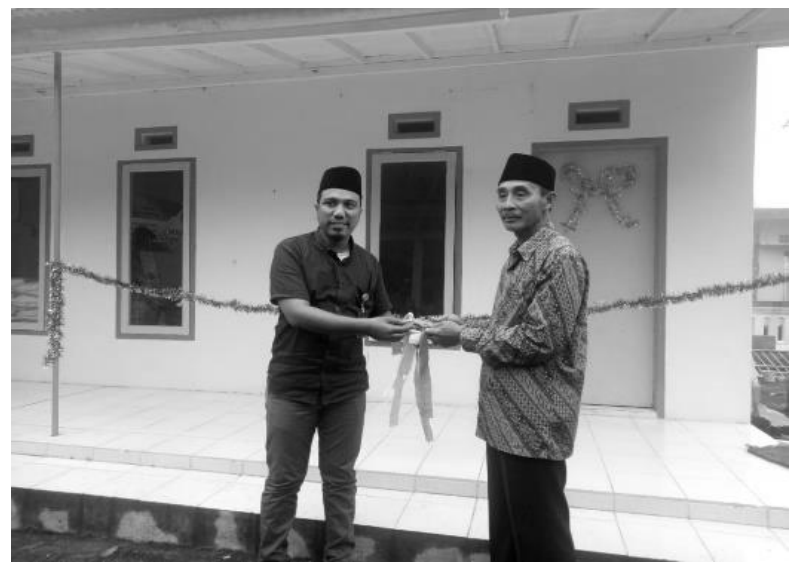

(e)

Gambar 3. Peresmian rumah baca masyarakat (d) Penyerahan rumah baca ke kepala desa

\section{KESIMPULAN}

Berdasarkan hasil dan pembahasan pengabdian tentang Penyediaan Rumah Baca Masyarakat Sebagai Solusi Cerdas Mengawali Budaya Membaca di desa Arguyuwono diatas, maka dapat disimpulkan

1. Masyarakat desa Arguyuwono sangat senang dengan adanya rumah baca masyarakat, karena mereka yakin penyediaan rumah baca ini akan mampu menjadi tempat yang kondusif untuk membangun generasi cerdas dan unggul di desa tersebut.

2. Rumah baca masyarakat ini mendapatkan dukungan dari berbagai pihak, baik dari aparatur desa, tokoh masyarakat, para guru dan juga masyarakat umum. 
3. Penyediaan rumah baca masyarakat juga sebagai upaya meningkatkan tingkat literasi masyarakat yang akan berdampak pada meningkatnya taraf hidup masyarakat di desa tersebut

4. Selanjutnya tentu diperlukan tambahan bacaan-bacaan yang baik sehingga dapat memperluas wawasan dan pengetahuan masyarakat di desa tersebut.

\section{UCAPAN TERIMA KASIH}

Penulis mengucapkan terima kasih kepada Lembaga Penelitian dan Pengabdian kepada Masyarakat Universitas Islam Malang (LPPM UNISMA) yang telah mendanai Pengabdian tentang Penyediaan Rumah Baca Sebagai Solusi Cerdas Mengawali Budaya Membaca di desa Arguyuwono tahun anggaran 2019.

\section{DAFTAR PUSTAKA}

Al-Rais, Fifqi. (2014). Perbedaan Pengungkapan Diri Mahasiswa Berdasar Tipe Kepribadian. Surabaya: UIN Sunan Ampel Surabaya.

Bano, J., Jabeen, Z., \& Qutoshi, S. B. (2018). Perceptions of Teachers about the Role of Parents in Developing Reading Habits of Children to Improve their Academic Performance in Schools. Journal of Education and Educational Developement, 42-59.

Esther Kartika. (2014). Memacu Minat Membaca Siswa Sekolah Dasar. Jurnal Pendidikan Penabur (Nomor 03 tahun III). Hlm. 113- 128.

Farida Rahim. (2008). Pengajaran Membaca di Sekolah Dasar: Edisi Kedua. Jakarta: Bumi Aksara.

Gustirianda, Salvia. (2014). Program Peningkatan Minat Baca Masyarakat Oleh Kantor Perpustakaan Arsip dan Dokumentasi Aceh Selatan. Fakultas Ilmu Budaya Universitas Sumatera Utara. Medan.

Harsiati, T., \& Priyatni, E. T. (2018). Karakteristik Tes Literasi Membaca Pada Programme For International Student Asessment (Pisa). BIBLIOTIKA : Jurnal Kajian Perpustakaan dan Informasi, 1(2), 1-11.

Hasanah, Muakibatul, Nurchasanah \& Hamidah, S. C. (2011). Membaca Ekstensif: Teori, Praktik, dan Pembelajaran. Malang: Pustaka Kaiswaran.

Huriyah, L. (2016). Peran Perpustakaan Keluarga Dalam Meningkatkan Minat Dan Keterampilan Membaca Anak. Journal of Islamic Education Studies , 70-95.

Jaka Satria Warman \& Vivi Mardian. (2019). Program Pelatihan Penigkatan Kemampuan Bahasa Inggris Anak-Anak Panti Asuhan Melalui Pemberdayaan Mahasiswa. DINAMISIA : Jurnal Pengabdian Kepada Masyarakat, vol. 3, no. 2, Hal. 280-285.

Iswari, Nurul. 2017. Ini Penyebab Rendahnya Minat Baca di Indonesia. Diakses melalui https://kumparan.com/nurul-iswari/ini-penyebab-rendahnya-minat-baca-diindonesia 1504967041086, diakses pada tanggal 4 April 2018.

Muhammad Yuliansyah \& Jarkawi. (2019). Pelatihan Strategi Menganalisis Masalah Siswa Dengan Psikoedukasi Pada Smk Di Kabupaten Banjar. DINAMISIA : Jurnal Pengabdian Kepada Masyarakat vol. 3, no. 2, Hal. 313 - 318. 